\title{
Literatur Review: Terapi Plasma Konvalesen bagi Pasien Covid-19
}

\author{
Literature Review of Convalessed Plasma Therapy for Covid-19 Patients \\ Francisca Romana Sri Supadmi ${ }^{1 *}$, Tri Djoko Endro Susilo ${ }^{1}$, Nurpuji Mumpuni ${ }^{1}$ \\ ${ }^{1}$ Prodi Teknologi Bank Darah, Fakultas Kesehatan, Universitas Jenderal Achmad Yani Yogyakarta \\ *Penulis korespondensi. Francisca Romana Sri Supadmi. Email: siskatbd.ayani@gmail.com
}

\begin{abstract}
ABSTRAK
Latar Belakang: Coronavirus Disease 2019 (Covid-19) disebabkan oleh Sars-CoV-2, dimana termasuk jenis virus corona, merupakan penyakit yang menyebabkan gangguan pernapasan akut dengan masa inkubasi rata-rata 5 hingga 14 hari. Pada kasus Covid-19 berat dapat menyebabkan pneumonia, sindrom pernapasan akut, gagal ginjal, dan bahkan kematian. Berbagai upaya telah dilakukan guna mencegah penyebaran infeksi, dengan dikeluarkannya berbagai protokol pencegahan dan penatalaksanaan terhadap pasien terinfeksi salah satunya terkait penggunaan plasma konvalesen sebagai terapi suportif. Pembahasan ini bertujuan untuk melihat bagaimana efektivitas penggunaan plasma konvalesen untuk terapi suportif pasien Covid-19

Metode: Jenis dan rancangan yang dipakai adalah literature review. Data yang digunakan adalah data sekunder berupa artikel atau jurnal dari penelitian terdahulu yang relevan dengan topik penelitian. Strategi pencarian data menggunakan database Google Scholar dan Pubmed. Seleksi studi dilakukan untuk menentukan artikel yang akan di-review. Dari 26 hasil pencarian terdapat jurnal terseleksi sesuai topik penelitian dan 18 jurnal tidak memenuhi kriteria inklusi dan ekslusi serta terdapat duplikasi data. Dari 8 jurnal terseleksi terpilih 2 jurnal yang sesuai topik Hasil catatan informasi dari artikel yang ditelaah disusun dalam tabel ektraksi data. Hasil literature review dianalisis dengan menggunakan tema sesuai temuan dari artikel.

Hasil: Terapi plasma konvalesen bagi pasien Covid-19 memperlihatkan perbaikan tanda dan gejala, peningkatan $P_{A} O 2 / F_{I} O 2$, perbaikan gambaran radiologi, peningkatan titer antibodi IgM dan IgG, pemulihan kondisi secara umum dan kesembuhan hingga pasien boleh pulang dari rumah sakit.

Kesimpulan: Terapi plasma konvalesen berpotensi efektif memperbaiki dan mengobati Covid-19.
\end{abstract}

Kata Kunci: Covid-19, SARS-CoV-2, terapi plasma konvalesen

\begin{abstract}
Background: Coronavirus Disease 2019 (Covid-19) is caused by Sars-CoV-2, the type of corona virus, which is a disease that causes acute respiratory distress with an average incubation period of 5 to 14 days. Severe cases of Covid19 can cause pneumonia, acute respiratory syndrome, kidney failure and even death. Various efforts have been made to prevent the spread of infection, with the issuance of various prevention and management protocols for infected patients, one of which is related to the use of convalescent plasma as supportive therapy. This study aims to see how the procedure for using convalescent plasma is for supportive therapy for Covid-19 patients.

Methods: The type and design of this study was a literature review. The data was secondary data in the form of articles or journals from previous studies that are relevant to the research topic. The collecting data strategy used the Google Scholar and Pubmed databases. Study selection was carried out to determine the articles to be reviewed. The results of information records from the articles reviewed were arranged in a data extraction table.

Result: Convalescent plasma therapy for Covid-19 patients showed improvement of signs and symptoms, PAO2 / FIO2, radiological images, IgM and IgG antibody titers, general recovery and recovery until the patient was discharged from the hospital.

Conclusion: Convalescent plasma therapy has a potential effect in repairing and treating Covid-19.
\end{abstract}

Keywords: Covid-19, SARS-CoV-2, convalescent plasma therapy 


\section{PENDAHULUAN}

Coronavirus Disease 2019 (Covid-19) yang disebabkan oleh Sars-CoV-2 termasuk jenis Virus corona, merupakan penyakit yang menyebabkan gangguan pernapasan akut seperti demam, batuk dan sesak napas dengan masa inkubasi rata-rata 5-6 hari dengan masa inkubasi terpanjang 14 hari. ${ }^{1,2}$ Pada kasus Covid-19 yang berat dapat menyebabkan pneumonia, sindrom pernapasan akut, gagal ginjal, dan bahkan kematian. ${ }^{3}$ Kasus Covid-19 teridentifikasi pertama kali di Wuhan, China pada tanggal 31 Desember 2019. Selanjutnya kasus ini berkembang dan terdapat laporan kematian serta penyebaran ke luar China. Pada tanggal 30 Januari 2020, World Health Organization (WHO) menetapkan Covid-19 sebagai Public Health Emergency of International Concern (PHEIC)/ Kedaruratan Kesehatan Masyarakat Yang Meresahkan Dunia (KKMMD). Oleh karena kasus semakin menyebar dengan pesat ke seluruh dunia, maka pada tanggal 11 Maret 2020 WHO menetapkan status Pandemi Coronavirus Disease 2019 (Covid-19). ${ }^{1,4}$

Data kasus Covid-19 sampai dengan 05 Agustus 2020, secara global dilaporkan terdapat 18.354. 342 kasus tersebar di 216 negara termasuk jumlah kematian 696.147 kasus. ${ }^{5}$ Covid-19 di Indonesia pertama kali teridentifikasi di daerah Jakarta, selanjutnya berkembang ke Jawa Barat, Jawa Tegah, Yogyakarta dan ke propinsi lain di Indonesia. Yogyakarta sebagai kota pelajar dengan penduduk dari berbagai propinsi dengan tingkat mobilitas yang tinggi sangat berpotensi terjadinya penularan yang tinggi. Data kasus Covid-19 secara nasional per 5 Agustus 2020 terdapat 116.871 kasus positif 73.889 kasus dinyatakan sembuh, dan 5.452 kasus meninggal dunia. ${ }^{6}$

Tingginya angka kematian disebabkan oleh karena banyak faktor, diantaranya adalah tingkat perkembangan virus dan adanya penyakit penyerta (komorbid) yang dimiliki pasien Covid-19 sebelumnya, belum adanya terapi spesifik untuk mengobati Covid-19. ${ }^{9}$
Pengobatan yang dilakukan ditujukan untuk mengatasi tanda dan gejala serta dampak yang diterima oleh penderita Covid-19, serta mencegah agar penyakit tidak berkembang menjadi lebih berat. WHO telah mengeluarkan berbagai kebijakan sebagai upaya untuk mencegah penyebaran infeksi Covid-19 dengan mengeluarkan berbagai protokol pencegahan dan penatalaksanaan terhadap pasien terinfeksi salah satunya terkait penggunaan plasma konvalesen sebagai terapi suportif untuk mengobati pasien Covid-19. ${ }^{1}$

Dengan berbekal pengalaman penggunaan plasma konvalesen untuk terapi pasien H1N1 influenza, Ebola pada tahun 2014, H5N1 (Flu burung), dan MERS CoV yang terbukti efektif menurunkan tingkat keparahan dan kematian ${ }^{9}$, diharapkan terapi plasma konvalesen juga mampu memberikan dampak yang baik dan harapan sembuh bagi pasien Covid-19. Hingga saat ini, belum ada protocol khusus tentang penggunaan plasma konalesen untuk terapi Covid-19. Penggunaan terapi saat ini masih dalam sebatas penelitian dan uji klinis. Berlatar belakang tersebut di atas, pembahasan ini bertujuan untuk melakukan review terhadap literatur yang ada terkait efektifitas penggunaan plasma konvalesen untuk terapi pasien Covid-19.

\section{METODE}

Jenis dan rancangan studi ini adalah literature review, yaitu studi yang mengkaji tulisan ilmiah, temuan hasil penelitian untuk mengintegrasikan dan menarik kesimpulan. Studi literatur yang digunakan terbatas pada bagaimana terapi plasma konvalesen pada pasien Covid-19. Literatur yang digunakan adalah jurnal dua tahun terakhir (JanuariAgustus 2020).

Data yang digunakan dalam studi ini adalah data sekunder yang diperoleh bukan dari pengamatan langsung, akan tetapi dari hasil penelitian yang telah dilakukan oleh peneliti terdahulu. Sumber data yang didapat berupa artikel atau jurnal yang relevan dengan 
topik efektivitas terapi plasma konvalesen bagi pasien Covid-19. Strategi pencarian data tersebut menggunakan database Google Scholar dan Pubmed. Kata kunci yang digunakan pada penelitian ini adalah "Treatment of Covid-19 Patient with Convalescent Plasma" OR "Convalescent Plasma Therapy in Covid-19 Patient" AND "Convalescent Plasma".

Kriteria inklusi pada studi ini adalah jurnal penelitian yang dipublikasikan bulan Januari - Agustus 2020, topik penelitian terkait efektivitas terapi plasma konvalesen bagi pasien Covid-19, dan Jurnal full teks. Kriteria eksklusi adalah jurnal di atas tahun 2019 tidak masuk dalam krieria ini, jurnal tidak full teks, dan tidak sesuai topik penelitian.

Seleksi studi dilakukan untuk menentukan artikel yang akan dipilih untuk direview. Seluruh jumlah artikel yang diperoleh dari database diseleksi; jika ditemukan duplikasi data, maka dihapus, selain itu diseleksi terkait relevansi judul dan abstrak, serta memasukkan kriteria inklusi dan eksklusi. Dari 26 hasil pencarian terdapat jurnal terseleksi sesuai topik penelitian dan 18 jurnal tidak memenuhi kriteria inklusi dan ekslusi serta terdapat duplikasi data. Dari 8 jurnal terseleksi terpilih 2 jurnal yang sesuai topik dengan tema terapi plasma konvalesen bagi pasien Covid-19. Hasil catatan informasi dari artikel jurnal yang ditelaah selanjutnya disusun dalam tabel ektrasi data. memuat materi yang ditemukan pada artikel yang ditelaah dan disesuaikan dengan informasi yang dibutuhkan. Hasil literature review dianalisis dengan menggunakan tema sesuai temuan dari artikel dan disajikan dalam tabel. Tema yang digunakan untuk menganalisis hasil pencarian pustaka adalah :
1. Kriteria pendonor
Plasma Konvalesen

2. Karakteristik pasien Covid-19 pada trial terapi plasma konvalesen
3. Aktivitas netralisasi antibodi SARS COV-2 pada plasma konvalesen
4. Prosedur transfusi plasma konvalesen pada pasien Covid-19

5. Hasil transfusi plasma konvalesen pada pasien Covid-19

Alur studi dengan mengikuti tahapan literature review seperti pada gambar 1 .

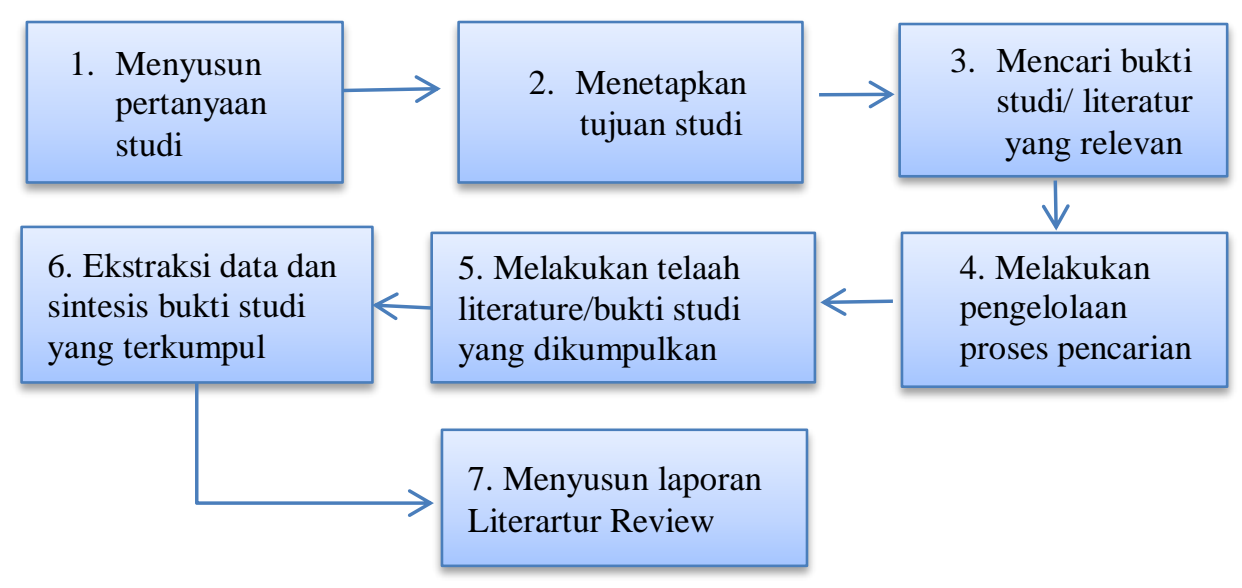

Gambar 1. Alur Studi

\section{HASIL DAN PEMBAHASAN}

\section{Hasil}

Hasil review dari jurnal yang terpilih sebagai berikut: 
1. Jurnal dari penulis $\mathrm{Ye}, \mathrm{Fu}$, Ren, Wang, et.al., 2020 yang diterbitkan pada J Med Virol. 2020;1-12 dengan judul Treatment with convalescent plasma for Covid-19 patients in Wuhan, China diperoleh hasil:

a. Definisi: Terapi Plasma Konvalesen merupakan prosedur transfusi plasma bagi pasien Covid-19 yang diambil dari seseorang yang telah sembuh dari Covid-19 dan memenuhi persyaratan sebagai pendonor darah

b. Metode: Uji klinis terhadap pasien Covid-19 yang dirawat di Wuhan Huoshenshan Hospital dari 11 Februari - 12 Maret 2020.

c. Pasien: telah terkonfirmasi melalui SARS-CoV-2 dengan pemeriksaan swab tenggorokan menggunakan RTPCR, pasien dengan kelainan pada hasil pemeriksaan Computed tomography (CT Scan) dada, pasien dengan gejala memburuk paska terapi standar, pasien dengan hasil persisten positif terhadap pemeriksaan swab tenggorokan, pasien kritis. Pasien dengan 5 kategori terdiri pasien persisten Covid-19, pasien konsolidasi, pasien dengan lesi paru yang luas, pasien dengan sindrom Sjögren, pasien dengan Ground-glass opacity (GGO). Jenis Kelamin pasien: Laki-laki tiga orang, perempuan 3 orang. Usia: lima pasien berusia lebih dari 50 tahun, dan satu orang berusia 28 tahun.

d. Pendonor: berasal dari pasien Covid19 yang telah sembuh, tidak mengalami demam kira-kira 3 hari, tidak terdapat gejala respiratori. Hasil RT-PCR dua kali negatif, tiga minggu telah dinyatakan sembuh. Seronegatif terhadap Anti-HBV, HCV, dan HIV, Seropositif terhadap Anti-SARS-CoV2. Pengukuran titer antibodi IgG dan IgM dengan menggunakan chemiluminescence.

e. Prosedur: Pemeriksaan golongan darah ABO kompatibel, Volume transfusi plasma satu kantong kira-kira $200 \mathrm{~mL}$ selama 30 menit setiap periode.
Setiap pasien mendapatkan plasma yang berbeda-beda. Pasien 1-3 rata-rata 3 kantong dalam 3-6 hari sekali dan pasien 4-6 masing-masing 1 kantong. Selama transfusi, pasien di bawah pengawasan dokter, pemeriksaan tanda vital setiap 15 menit dan empat jam setelah pemberian transfusi.

f. Hasil: Mayoritas terdapat perbaikan gejala dan gambaran radiologi setelah mendapatkan transfusi plasma konvalesen. Terdapat peningkatan titer antibodi IgM dan IgG sebelum dan sesudah mendapatkan transfusi. Ttiter IgM dari ke-6 pasien sebelum transfusi rata-rata antara 16-104, Titer IgG antara 72-205. Titer antibodi IgG pasca transfusi rata-rata dari ke-6 pasien 27 477, dan titer IgG meningkat menjadi 170 - 258. Inverval waktu mulai dari onset hingga dirawat rata-rata $24-25$ hari dari interval mulai dirawat hingga ditransfusi rata-rata 18-19 hari. Pasien sembuh dan boleh pulang dari rumah sakit.

2. Jurnal dari penulis Shen, Wang, Zhao, et.al., 2020 yang diterbitkan di JAMA. 2020;323(16):1582-1589 dengan judul Treatment of 5 Critically Ill Patients With Covid-19 With Convalescent Plasma, didapatkan hasil sebagai berikut :

a. Definisi: Terapi Plasma Konvalesen merupakan terapi transfusi plasma bagi pasien Covid-19 yang diambil dari seseorang yang telah sembuh dari Covid-19 1-2 minggu dan memenuhi persyaratan sebagai pendonor darah

b. Metode: Uji klinis, dilakukan di departemen penyakit infeksi Shenzhen Third People's Hospital, Shenzhen, China, terhadap pasien yang terkonfirmasi Covid-19 dari tanggal 20 Januari - 25 Maret 2020.

c. Pasien: 5 orang terkonfirmasi Covid19 dengan RT PCR dan accute respiratory distress syndrome (ARDS) dengan kriteria pneumonia berat dengan peningkatan jumlah virus yang cepat dan terus-menerus, mendapatkan 
terapi antivirus dan steroid, rasio tekanan parsial arteri terhadap fraksi Oksigen inspirasi $\left(\mathrm{P}_{\mathrm{A}} \mathrm{O}_{2} / \mathrm{F}_{\mathrm{I}} \mathrm{O}_{2}\right)<300$, mendapatkan terapi suportif ventilasi mekanik.Usia pasien antara $30-70$ tahun, Jenis kelamin 3 orang laki-laki dan 2 orang perempuan.

d. Pendonor: 5 orang pendonor yang telah sembuh dari infeksi SARS-CoV-2 yang bersedia mendonorkan plasma konvalesen dengan informed consent. Interval antara munculnya tanda dan gejala onset hingga boleh pulang ratarata 12 hari dan jarak dari saat pulang hingga saat donasi rata-rata 12 hari. Pendonor terkonfirmasi negatif terhadap SARS CoV-2, sero positif SARS-CoV-2, seronegatif HBV, HCV, HIV, dan Sifilis, tanpa gejala selama 10 hari terakhir, pengukuran titer antibodi $\operatorname{IgG}$ rata-rata 8.280,titer $\operatorname{IgM}$ 6.840, dan titer dan titer antibodi netralisasi rata-rata 232 (syarat harus > 40). Usia pendonor antara $18-60$ tahun, Volume donasi $400 \mathrm{~mL}$ dengan apheresis.

e. Prosedur: Pemeriksaan golongan darah ABO kompatibel, setiap pasien mendapatkan 2 kali transfusi dengan volume antara 200-300 mL per kantong pada hari yang sama dan diberikan antivirus secara terus-menerus hingga viral load negatif. Pengukuran antibodi netralisasi diukur dengan ELISA setiap hari setelah mendapatkan transfusi. Selama terapi, informasi klinis dicatat ke dalam sistem informasi manajemen rumah sakit meliputi informasi demografi, riwayat penyakit, riwayat terapi, riwayat medis, data hasil pemeriksaan laboratorium, dan informasi komplikasi. Transfusi diberikan 10-22 hari setelah setelah admisi.

f. Hasil: Hasil pengukuran sebelum transfusi dan 1-12 hari pasca transfusi terhadap tanda vital meliputi suhu tubuh rata-rata dari ke-5 pasien pada awal infeksi $38.5^{\circ} \mathrm{C}$ menurun hingga rata-rata $37.02^{\circ} \mathrm{C}$. Pengukuran Skor Sequential Organ Failure Assessment (SOFA) rata-rata 4.6 menurun hingga rata-rata 2 pasca transfusi. Status oksigenasi $\left(\mathrm{P}_{\mathrm{A}} \mathrm{O}_{2} / \mathrm{F}_{\mathrm{I}} \mathrm{O}_{2}\right) \quad$ pasien mengalami perbaikan sebelum transfusi rata-rata 210.2 menjadi 326 , viral load proxy (CT Scan) pada awal admisi hingga pada saat transfusi antara 18.9 38.0 menjadi 22.0 - 35.9 menurun pasca transfusi dan hasilnya negatif setelah hari ke-12 pasca transfusi. Hasil pengukuran titer antibodi pasien sebelum transfusi rata-rata antara 40160 , terjadi peningkatan pada hari ke-7 dan terus meningkat hingga hari ke-12 pasca transfusi menjadi antara 160 480. Pasien sembuh dan boleh pulang dari rumah sakit.

\section{Pembahasan}

Hasil penelusuran literatur menurut Ye et. al., dan Shen et. al. terapi plasma konvalesen merupakan pemberian transfusi plasma bagi pasien Covid-19 yang diambil dari pasien Covid-19 sekitar 14 hari (dua minggu) setelah dinyatakan sembuh, tanpa menunjukkan gejala dalam 10 hari terakhir dan memenuhi persyaratan sebagai pendonor darah. ${ }^{10,11}$ Penggunaan plasma konvalesen sebagai terapi telah lama digunakan, bahkan diperkirakan mulai dari 100 tahun yang lalu. Terapi plasma konvalesen telah digunakan untuk profilaksis atau pemberian plasma untuk tujuan peningkatan kekebalan secara pasif maupun pengobatan untuk berbagai penyakit menular teutama pada saat terjadi wabah seperti polio, campak, Ebola, dan pada saat terjadinya pandemi penyakit menular seperti HIV, SARS, MERS, H1N1, dan H5N1. ${ }^{12}$

Penelitian terdahulu pada tahun 2003, ketika terjadi outbreak SARS, Cheng et.al melaporkan hasil penelitian terhadap 80 pasien SARS di Hongkong yang diberikan terapi plasma konvalesen, semua memperoleh dampak klinis yang baik dan memberikan harapan sembuh lebih besar. Tigapuluh tiga diantaranya mengalami perbaikan klinis jauh 
lebih baik dibandingkan dengan 47 pasien lainnya dikarenakan pemberian transfusi dilakukan pada tahap awal infeksi sebelum berkembang menjadi lebih berat. ${ }^{12}$

Penggunaan plasma konvalesen pada kasus Covid-19, diharapkan juga dapat menjadi pilihan alternatif untuk mengatasi dan mengobati pasien Covid-19. Hasil review dari penelitian terdahulu menyatakan, kriteria pasien penerima terapi plasma konvalesen pada pasien Covid-19 mayoritas pada usia di atas 50 tahun, dan dalam kondisi kritis, serta memiliki komorbid atau penyakit penyerta. Jika kembali ke pengalaman terapi plasma konvalesen pada pasien SARS di Hongkong tahun 2003 dan wilayah lain, dampak klinis yang lebih baik diterima oleh pasien mendapatkan terapi pada tahap awal infeksi. Oleh karena peluang kesembuhan lebih besar dibandingkan dengan pasien yang diterapi ketika kondisi pasien sudah berat. Hal ini tentu dapat menjadi pertimbangan bagi para pemangku kebijakan dalam membuat protokol terapi plasma konvalesen nantinya terkait dengan kriteria pasien penerima plasma konvalesen agar hasil terapi memberikan dampak yang lebih besar bagi penderita berapapun usianya. ${ }^{12}$

Hasil penelusuran artikel terkait dengan karakteristik pendonor plasma konvalesen, Ye et. al maupun Shen et. al keduanya menyatakan bahwa pendonor plasma konvalesen adalah pasien Covid-19 yang telah dinyatakan sembuh dan terkonfirmasi melalui pemeriksaan swab dengan PCR sebanyak dua kali dengan hasil negatif, namun seropositive terhadap SARS CoV-2. Pengukuran titer antibodi IgM, IgG, dan antibodi netralisasi juga harus dilakukan sebelum donasi, apalagi jika masih dalam tahap uji klinis. Hal ini dilakukan guna mengetahui seberapa aktifitas netralisasi antibodi melawan antigen virus sehingga mampu menekan laju pertumbuhan virus menjadi negatif. Selain pemeriksaan konfirmasi dan titer antibodi, calon pendonor harus memenuhi persyaratan calon pendonor darah secara umum, diantaranya harus seronegatif terhadap HIV, HBV, HCV, dan
Sifilis. Calon pendonor plasma konvalesen disarankan berasal dari daerah yang sama mengingat hingga saat ini, belum diketahui biologi molekuler secara pasti dari setiap virus oleh karena kemampuan mutasinya yang amat tinggi. ${ }^{13,14}$

Permasalahan yang dihadapai untuk saat ini, belum semua pasien Covid-19 yang telah sembuh, bersedia untuk menjadi pendonor plasma konvalesen dikarenakan mereka merasa belum sehat, da nada kekhawatiran jika darahnya diambil akan berdampak pada kesehatannya. Hali ini menjadi tantangan tersendiri bagi pusat pelayanan darah dalam melakukan rekrutmen calon pendonor plasma konvalesen. Dukungan dan kerjasama dari berbagai pihak terutama rumah sakit rujukan pasien Covid-19, Dinas Kesehatan, dan Unit Transfusi Darah sebagai lembaga penyedia darah serta masyarakat secara umum untuk melakukan sosialisasi mengenai bagaimana pentingnya melakukan donasi bagi pasien Covid-19 yang telah sembuh. Selain tantangan terkait rekrutmen, ketersediaan sumberdaya untuk pemeriksaan titer antibodi harus lebih luas dan terjangkau sehingga plasma konvalesen dapat disiapkan di berbagai daerah.

Kegiatan rekrutmen harus dilakukan dengan gencar pada saat kasus masih tinggi, agar didapatkan lebih banyak calon pendonor plasma konvalesen. Jika banyak calon pendonor yang bersedia melakukan donasi dan dapat diambil plasmanya, tentu akan meningkatkan stok dan menjamin ketersediaan plasma konvalesen bagi pasien Covid-19 yang membutuhkan. Plasma konvalesen dapat disimpan dalam bentuk beku (Fresh Frozen Plasma) sehingga masa simpannya menjadi lebih panjang antara tiga bulan hingga satu tahun jika disimpan pada suhu $-20^{\circ} \mathrm{C}$ atau lebih dingin.

Peneliti terdahulu melaporkan, bahwa prosedur penyediaan plasma konvalesen dilakukan dengan metode apheresis dan sesuai dengan protocol Covid-19. Pengambilan darah dengan apheresis telah terbukti lebih aman dan lebih baik, namun membutuhkan sumber daya manusia, 
peralatan, dan kit apheresis dengan biaya yang masih belum terjangkau secara umum terutama bagi masyarakat Indonesia. Hal ini menjadi tantangan tersendiri bagi pemerintah dan para pemegang otoritas dalam membuat kebijakan terkait penyiapan plasma konvalesen dengan metode konvensional (pengambilan darah lengkap). Jika plasma konvalesen dapat disiapkan melalui pengambilan darah lengkap, maka penyiapan plasma konvalesen dapat dilakukan oleh Unit Transfusi Darah yang belum memiliki fasilitas apheresis, yang pada akhirnya berdampak pada lebih luasnya pemanfaatan plasma konvalesen bagi masyarakat.

Prosedur transfusi plasma konvalesen baik Ye et. al., dan Shen et. al., melaporkan bahwa sebelum tindakan transfusi, harus melalui uji kompatibilitas golongan darah $\mathrm{ABO}$ dan pengukuran titer antibodi sebelum dan setelah dilakukan transfusi. Monitoring terhadap tanda vital dilakukan setiap 15 menit selama transfusi dan empat jam pasca transfusi. Pemberian transfusi menggunakan volume rata-rata $200-300 \mathrm{ml}$ setiap periode dengan jumlah total kantong sesuai dengan kebutuhan pasien dan pertimbangan klinis dokter. Selama transfusi, pasien tetap diberikan terapi utama dan terapi penunjang lainnya seperti steroid dan antivirus secara terus-menerus hingga viral load negatif. Pencatatan dan dokumentasi terhadap informasi klinis selama transfusi dilakukan melalui sistem informasi manajemen rumah sakit. Informasi pasien meliputi demografi, riwayat penyakit, riwayat terapi, riwayat medis, dan data hasil pemeriksaan laboratorium, serta informasi komplikasi. Transfusi dapat dilakukan sesegera mungkin tanpa harus menunggu penyakit berkembang menjadi lebih berat dan disesuaikan dengan ketersediaan plasma konvalesen.

Virus SAR CoV-2 dilaporkan memiliki kemampuan bermutasi yang begitu cepat. Kemudahan transmisi dan jangkauan wilayah paparan yang begitu luas di berbagai wilayah di dunia, tentu semakin mempersulit ditemukannya vaksin untuk Covid-19. Pengobatan untuk Covid-19 pun hingga saat ini belum ada yang spesifik. Para peneliti melaporkan hasil evaluasi transfusi plasma konvalesen selama pandemi pada pasien Covid-19, seluruh pasien yang mendapatkan terapi dengan plasma konvalesen mengalami perbaikan klinis yang signifikan serta tidak terdapat efek samping yang serius. . $^{, 15-17}$ Berdasar berbagai pertimbangan tersebut di atas, serta berdasarkan evaluasi penggunaan plasma konvalesen baik untuk pengobatan SARS, MERS, Ebola, dan infeksi menular lain di masa lalu, pengalaman terapi plasma konvalesen pada Covid-19 pada uji klinis di saat pandemi, serta kemungkinan tingkat kemudahan penyediaan plasma konvalesen di masa yang akan datang, maka terapi plasma konvalesen dapat menjadi pilihan bijak guna mengatasi Covid-19.

\section{Kesimpulan}

Terapi plasma konvalesen merupakan terapi transfusi plasma bagi pasien Covid-19 yang diambil dari seseorang yang telah sembuh dari Covid-19 kira-kira dua - tiga minggu, tidak menunjukkan tanda dan gejala dalam waktu 10 hari terakhir, serta memenuhi persyaratan sebagai calon pendonor darah. Kriteria pasien penerima terapi plasma konvalesen adalah pasien Covid-19 yang telah terkonfirmasi dengan swab tenggorokan menggunakan RT PCR, menunjukkan tanda dan gejala ke arah perkembangan penyakit, dan kondisi kritis. Pendonor plasma konvalesen merupakan pasien yang telah sembuh dari infeksi Covid-19, telah terkonfirmasi dengan hasil swab negatif dengan RT PCR, tidak ada tanda dan gejala dalam 10 hari terakhir, seropositif terhadap Anti-SARS CoV-2, seronegatif terhadap HBV, HCV, HIV, dan Sifilis,serta memiliki titer antibodi poliklonal (IgM dan IgG) yang tinggi, serta titer antibodi netralisasi $>40$. Prosedur terapi plasma konvalesen diberikan kepada pasien Covid-19 yang memenuhi kriteria, dengan dosis antara 200-300 ml setiap periodde transfusi, di bawah pengawasan dokter dan dilakukan monitoring terhadap tanda vital pasien selama prosedur 
transfusi dan setelah empat jam setelah transfusi. Pengukuran titer antibody IgM dan IgG serta antibodi netralisasi dilakukan sebelum dan setelah mendapatkan transfusi untuk melihat seberapa kemampuan antibodi melawan antigen virus. Hasil evaluasi terapi plasma konvalesen pada pasien Covid-19, semua menunjukkan perbaikan tanda vital dan gejala klinis, perbaikan gambaran radiologi, terdapat peningkatan titer antibodi baik IgM, IgG, dan netralisasi pasca transfusi yang menandakan perbaikan kondisi pasien ke arah yang lebih baik, serta tidak ada efek yang serius. Belum adanya terapi yang spesfifik, sulitnya mendapatkan vaksin yang tepat, pengalaman penggunaan plasma konvalesen di masal lalu untuk terapi berbagai infeksi menular pada saat terjadinya wabah dan pandemi, serta adanya kemungkinan tingkat kemudahan penyiapan, maka terapi plasma konvalesen dapat menjadi pilihan bijak untuk mengatasi Covid-19.

\section{DAFTAR PUSTAKA}

1. Sohrabi C, Alsafi Z, O’Neil N, Khan M, Kerwan A, Al-Jabir A, et. al. World health organization declares global emergency: a review of the 2019 novel coronavirus (covid-19). International Journal of Surgery. 2020;76: 71-76

2. Huang C, Wang Y, Li X, Ren L,Zhao J, $\mathrm{Hu} \mathrm{Y}$, et. al. Clinical features of patients infected with 2019 novel coronavirus in wuhan, china. The Lancet. 2020;395(10223): 497-506

3. Zhou M, Zhang X, Qu J. Coronavirus disease 2019 (covid-19): a clinical update. Frontiers of medicine. 2020;14(2): 126-135

4. Griensven JV, Edwards T, Lamballerie XD, Semple MG, Gallian P, Baize S, et.al. Evaluation of convalescent plasma for Ebola virus disease in Guinea. $N$. Engl. J. Med. 2016;374: 33-42

5. World Health Organization(WHO). WHO coronavirus disease (covid-19) dashboard. 2020. Available from: URL HIPERLINK: https://covid19.who.int/
6. S. P. Covid-19. Situasi virus covid-19 di indonesia: sebaran data. 2020.Available from: URL HIPERLINK: https://covid19.go.id/

7. Zeng F, Chen X, Deng G. Convalescent plasma for patients with covid-19. Proceedings of the national academy of sciences of the united states of america. 2020 June 9. USA;PNAS;2020

8. Houng HSH, Norwood D, Ludwig GV, Sun W, Lin M, Vaughn DW. Development and evaluation of an efficient 3'-noncoding region based SARS coronavirus (SARS-CoV) RTPCR assay for detection of SARS-CoV infections. J. Virol. Methods, 2004;120(1): 33-40

9. Shen C, Wang Z, Zhao F, Yang Y, Li J, Yuan J, et. al. Treatment of 5 critically ill patients with covid-19 with convalescent plasma," JAMA. 2020;323(16): 15821589

10. Ye M, Fu D, Ren Y, Wang F, Wang D, Zhang $F$, et. al. Treatment with convalescent plasma for covid-19 patients in wuhan, china. J. Med. Virol. 2020;92(10): 1890-1901

11. Cheng Y, Wong R, Soo YOY, Wong WS, Lee CK, Chan P, et. al. Use of convalescent plasma therapy in SARS patients in Hong Kong. Eur $J$ Clin Microbiol Infect Dis. 2005;24(1): 44-46

12. Chan JFW, Kok KH, Zhu Z, Chu H, To KKW, Yuan S. et. al. Genomic characterization of the 2019 novel human-pathogenic coronavirus isolated from a patient with atypical pneumonia after visiting Wuhan. Emerging Microbes \& Infections. 2020;9(1): 221-236

13. Khailany RA, Safdar M, Ozaslan M. Genomic characterization of a novel SARS-CoV-2. Gene Reports. 2020;19: 100682.doi:10.1016/j.genrep.2020.10068 2.

14. Ahn JY, Sohn Y, Lee SH, Cho Y, Hyun $\mathrm{JH}$, Baek YJ, et. Al. Use of convalescent plasma therapy in two covid-19 patients with acute respiratory distress syndrome 
in Korea. J. Korean Med. Sci. 2020;35(14): e149

15. Leal JFC. Safety in Convalescent Plasma Transfusion to COVID-19. Hospital San José Tec de Monterrey, Tenologio de Moterrey; 2020. ClinicalTrials.gov Identifier: NCT04333355 